\title{
Vertical transmission of Toxocara canis in successive generations of mice
}

\author{
Transmissão vertical de Toxocara canis em geraçóes sucessivas de camundongos \\ Elizandra Roselaine Schoenardie ${ }^{1}$; Carlos James Scaini ${ }^{2}$; Michele Soares Pepe ${ }^{1}$; Sibele Borsuk ${ }^{3}$; \\ Luciana Farias da Costa de Avila ${ }^{1}$; Marcos Villela ${ }^{1}$; Maria Elisabeth Aires Berne ${ }^{1 *}$
}

\begin{abstract}
${ }^{1}$ Departamento de Microbiologia e Parasitologia, Instituto de Biologia, Universidade Federal de Pelotas -UFPEL, Campus Capão do Leão, Pelotas, RS, Brasil

${ }^{2}$ Programa de Pós-graduação em Ciências da Saúde, Universidade Federal do Rio Grande - FURG, Rio Grande, RS, Brasil

${ }^{3}$ Núcleo de Biotecnologia, Centro de Desenvolvimento Tecnológico, Universidade Federal de Pelotas - UFPEL, Pelotas, RS, Brasil
\end{abstract}

Received August 19, 2013

Accepted November 5, 2013

\begin{abstract}
Visceral toxocariasis is a neglected zoonosis caused by Toxocara canis larvae in unusual hosts. In dogs, the definitive host, the infection occurs mainly through transplacental and transcolostral transmission. Studies on experimental models have shown that vertical transmission may result from acute infections. Considering that toxocariasis is characterized as a chronic infection, with possible reactivation of larvae present in the brain, this study evaluated the presence of larvae in the brain of female BALB/c mice and their offspring with chronic infection during three successive pregnancies. ELISA-TES was used to evaluate the antibody levels. T. canis larvae were detected in the brain tissue of the mice during the three successive generations evaluated. The offspring's IgG level gradually decreased, and mean absorbance (ABS) above the cutoff point (0.070) was observed only at $30(0.229)$ and $50(0.096)$ days of age, while IgM was not detected. The infections in the offspring confirmed that vertical transmission of T. canis larvae occurred during chronic toxocariasis in three successive generations of mice.
\end{abstract}

Keywords: Visceral larva migrans, Toxocara canis, vertical transmission, BALB/c mice, ELISA - TES.

\section{Resumo}

A toxocaríase visceral é uma zoonose negligenciada causada por larvas de Toxocara canis em hospedeiros não usuais. Em cães, os hospedeiros definitivos, a infecção ocorre normalmente por transmissão transplacentária e através do colostro. Estudos com modelos experimentais têm demonstrado a ocorrência de transmissão vertical durante a infecçáo aguda. Considerando que a toxocaríase é caracterizada como uma infecção crônica, com uma possível reativação das larvas presentes no cérebro, este estudo avaliou a presença de larvas no cérebro de camundongos Balb/C fêmeas e suas proles com infecção crônica durante três gestaçóes sucessivas. Para avaliar os níveis de anticorpos foi utilizado ELISA-TES. Larvas de T. canis foram detectadas no encéfalo dos animais durante as três geraçóes sucessivas avaliadas. O nível de IgG das proles foi diminuindo gradualmente e as médias de absorbâncias (ABS) acima do ponto de corte $(0,070)$ foram evidenciadas somente aos $30(0,229)$ e 50 dias $(0,096)$ de vida, enquanto que não foi detectada IgM. Infecções das proles confirmam a transmissão vertical de larvas de T. canis durante a toxocaríase crônica em três geraçóes sucessivas de camundongos.

Palavras-chave: Larva migrans visceral, Toxocara canis, transmissão vertical, camundongos BALB/c, ELISA - TES.

Visceral toxocariasis, also known as visceral larva migrans (VLM) syndrome, is defined as the migration and persistence of helminthic larvae in tissues of unusual hosts (BEAVER, 1969),

\footnotetext{
*Corresponding author: Maria Elisabeth Aires Berne

Departamento de Microbiologia e Parasitologia, Instituto de Biologia,

Universidade Federal de Pelotas - UFPEL, Campus Universitário, s/n.,

CP 354, CEP 96010-900, Pelotas, RS, Brasil

e-mail: bernemea@gmail.com
}

and it is a zoonosis that presents a continuing public health risk. The nematode Toxocara canis, a small intestine parasite in dogs, is the etiological agent most commonly associated with this zoonosis. In dogs, the zoonotic profile is maintained by transplacental and transmammary infection (BURKE; ROBERSON, 1985), in which the young animals are more susceptible and also the main disseminators of eggs in the environment (GALLINA et al., 2011; OLIVEIRA-SEQUEIRA et al., 2002; VILLELA et al., 2009). 
In humans, visceral toxocariasis is characterized by chronic infection that can persist for several years with possible reactivation and larval migration to the eyes and brain (PAWLOWSKI, 2001). The clinical symptoms of toxocariasis vary depending on the tissue parasitized, the number of eggs ingested and the immune response of the host (GLICKMAN et al. 1979). Epidemiological studies in various countries have shown that toxocariasis is common in humans (CHIEFFI et al., 2009; COLLI et al., 2010; SARIEGO et al., 2012; ALVARADO-ESQUIVEL, 2013). Accidental ingestion of embryonated $T$. canis eggs is the main infection path in humans, but is not the only route. Larvae present in undercooked meats may also cause infection (HOFFMEISTER et al., 2007; DUTRA et al., 2013).

Almost two decades ago, Anderson (1996) warned of the need to pay attention to pregnant women, because $T$. canis larvae could be transmitted to the fetus when the mother acquired an infection during pregnancy. A few years later, a case of congenital newborn infection was recorded in Argentina, in a premature infant with retinopathy (MAFFRAND et al., 2006). To simulate this form of transmission in the human hosts, mice have been used (REITEROVÁ et al., 2003; JIN et al., 2008), since they have the same migration behavior and develop the disease in the same was as in accidental hosts (CAMPAROTO et al., 2008; HOLLAND; COX, 2001). To assess the importance of this infection route, the present study evaluated vertical transmission of $T$. canis in BALB/c mice with chronic infections during three successive pregnancies.

$T$. canis eggs were collected from the uterine tubes of adult female parasites that had been obtained through treating young dogs with pyrantel pamoate $(15 \mathrm{mg} / \mathrm{kg})$. Afterwards, the eggs were incubated in a $2 \%$ formalin solution at $28^{\circ} \mathrm{C}$ for 30 days. Experimental infection was performed in five female BALB/c mice (at 8 weeks of age), which was done through intraperitoneal inoculation of 1,200 T. canis larvae. Ninety days after the inoculation (chronic infection), they were mated with males of the same age and observed for a period of 120 days. Blood was collected on the first mating day and from the three offspring sets at 30, 50, 70, 90, and 110 days of age. The presence of T. canis larvae in the brain tissue of the female mice was evaluated 120 days after mating (210 days after infection), and in their respective offspring (43 animals in total) at 110 days of age, from the three successive generations. To investigate the presence of T. canis infection in the female mice and their offspring, brain fragments were compressed between glass slides and examined under a microscope at 100× (KAYES; OAKS, 1976). The IgG and IgM levels were evaluated using ELISA and TES antigen production, following the protocol of De Savigny (1975). This study was approved by the Ethics Committee for Animal Experimentation at the Federal University of Pelotas (CEEA no. 6554). The occurrence of vertical transmission was calculated. For statistical analysis, we used the Minitab software, version 15, and used Student's t test. P-value greater than 0.05 were considered to be not significant.

In this study, T. canis larvae was detected in all the three successive generations of mice evaluated (Table 1). However, the variation in the numbers of larvae diagnosed in the brain of each female mouse indicated that there was no statistically significant correlation between the number of mice born in the three generations and the number of larvae found in the brains of these offspring ( $p>0.05)$. The larvae detected in the brain tissue (total of 141 larvae) were alive, thus confirming that there was chronic infection among the female mice. At the first mating, corresponding to 90 days of infection, the females mice had high levels of $\operatorname{IgG}$ and $\operatorname{IgM}(\mathrm{p}<0.05)$, and mean ABS of 1.280 and 0.685 respectively, which is typical of the chronic phase. According to Fan et al. (2003), IgG levels are maintained in sera from infected mice for long periods (up to 67 weeks post-infection).

In the offspring, the IgG levels decreased from the age of 30 day to 50 days, and greater reductions were detected at 70 days (Figure 1), thus characterizing vertical transfer of maternal antibodies (YAMASHITA et al., 2006). Moreover, the IgM levels were not significant, remaining lower than the cutoff from 30 to 110 days of age (Table 2).

Similar results were obtained by Bowman et al. (1987) who observed higher levels of IgM (between 42 and 70 days) and IgG (between 70 and 90 days) in female mice with chronic infection.

In the present study, out of the five female mice with chronic infections, three had T. canis larvae in their brain tissues and in their offspring's brain tissue: two from the first generation, one from the second generation and two from the third generation of offspring. All the larvae detected showed motility and no tissue reaction was found. Similar results have been obtained from mice 122 days after infection, in which viable T. canis larvae were detected in brain tissues with no correlated inflammatory reaction (DUNSMORE et al., 1983; FAN et al., 2003).

The re-emergence of $T$. canis larvae during pregnancy and vertical transmission in dogs are well known in relation to the biological cycle of this nematode (BURKE; ROBERSON, 1985). We demonstrated the importance of vertical transmission of T. canis in successive generations of mice with chronic infection.

Table 1. Toxocara canis larvae in brain tissue from female BALB/c mice and their offspring with chronic infection.

\begin{tabular}{|c|c|c|c|c|c|c|c|}
\hline \multirow{2}{*}{$\begin{array}{l}\text { Infected female } \\
\text { mice }\end{array}$} & \multirow[t]{2}{*}{ No. of larvae } & \multicolumn{3}{|c|}{ No. of mice born from three generations } & \multicolumn{3}{|c|}{$\begin{array}{l}\text { No. of larvae in the brain of offspring } \\
\text { in three generations }\end{array}$} \\
\hline & & $1^{\text {st }}$ & $2^{\text {nd }}$ & $3^{\text {rd }}$ & $1^{\text {st }}$ & $2^{\text {nd }}$ & $3^{\text {rd }}$ \\
\hline 1 & 10 & 5 & 3 & 2 & 1 & 1 & 0 \\
\hline 2 & 3 & 2 & 5 & 1 & 1 & 0 & 0 \\
\hline 3 & 54 & 5 & 1 & 2 & 0 & 0 & 0 \\
\hline 4 & 18 & 2 & 2 & 3 & 0 & 0 & 0 \\
\hline 5 & 34 & 5 & 1 & 4 & 0 & 0 & 2 \\
\hline Total & 141 & 19 & 12 & 12 & 2 & 1 & 2 \\
\hline
\end{tabular}




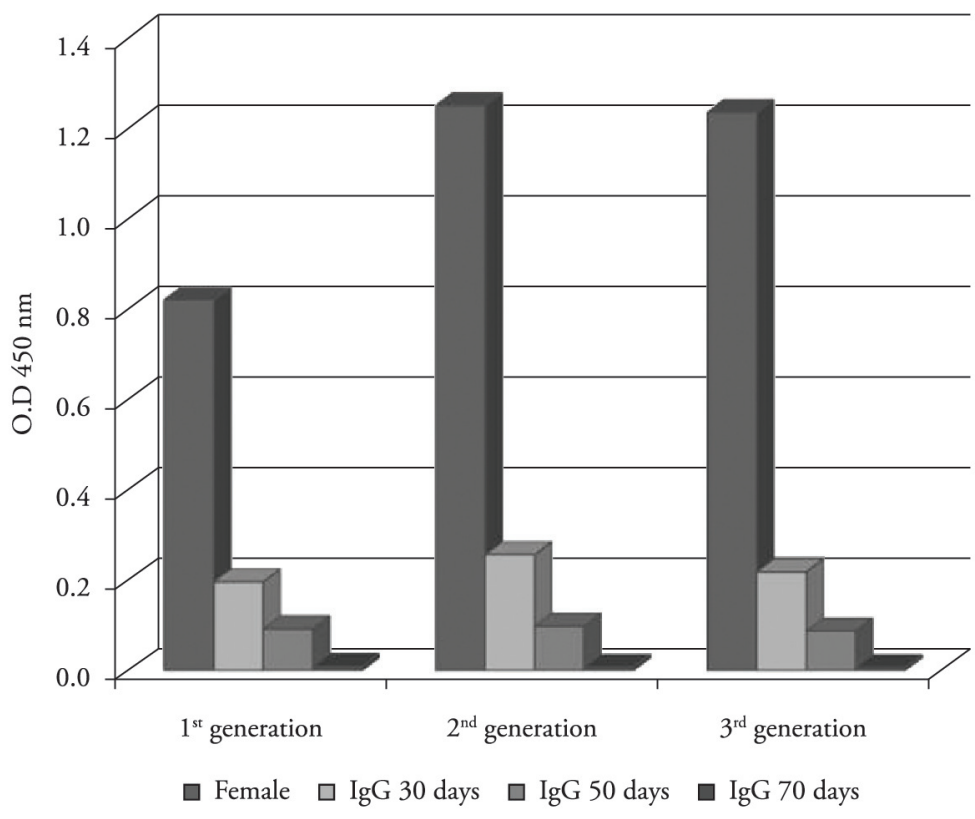

Figure 1. ELISA-TES on female BALB/c mice on the day of first mating, and their offspring at 30, 50 and 70 days of age, in three consecutive pregnancies.

Table 2. Immunoglobulin production against Toxocara canis detected by ELISA in offspring BALB/c mice from three successive generations, correlated with the presence or absence of T. canis larvae in the brain tissue. The values of IgG and IgM represent the mean value.

\begin{tabular}{cccccccc}
\hline \multirow{2}{*}{ T. canis larvae } & \multirow{2}{*}{ No. of animals } & \multicolumn{3}{c}{ ELISA/IgG } & \multicolumn{3}{c}{ ELISA/IgM } \\
\cline { 2 - 8 } & & day $\mathbf{3 0}$ & day $\mathbf{5 0}$ & day 70 & day 30 & day 50 & day 70 \\
\hline Presence & 5 & 0.281 & 0.103 & 0.019 & 0.035 & 0.014 & 0.013 \\
Absence & 38 & 0.223 & 0.095 & 0.015 & 0.028 & 0.018 & 0.017 \\
\hline
\end{tabular}

ELISA/IgG cutoff: 0.070 ELISA/IgM cutoff: 0.066.

Most studies on vertical transmission of $T$. canis have been conducted during the acute phase of infection (LEE et al., 1976; REITEROVÁ et al., 2003; JIN et al., 2008), although there is one record of vertical transmission of $T$. canis during the chronic phase in BALB/c mice (AVILA et al., 2009). With infections occurring during pregnancy, the likelihood that $T$. canis larvae will reach the fetus is greater because of their presence (during the acute phase) in liver and lung tissue (ABO-SHEHADA; HERBERT, 1984). In the chronic phase, which usually begins 40 days after infection, the accumulation of $T$. canis larvae in the brain favors vertical transmission of the parasite, since the larvae may remain viable in this tissue for months or even years (DUNSMORE, 1983). The infections described in the offspring demonstrated that vertical transmission occurred in these mice presenting chronic toxocariasis during successive pregnancies. However, determination of the transmission route, which could be either transplacental or transcolostral, and the related immunological responses, remains necessary.

\section{References}

Abo-Shehada MN, Herbert IV. The migration of larval Toxocara canis in mice. II. Post-intestinal migration in primary infections. Vet Parasitol 1984; 17(1):75-83. http://dx.doi.org/10.1016/03044017(84)90066-9
Alvarado-Esquivel C. Toxocariasis in Waste Pickers: A Case Control Seroprevalence Study. PLoS One 2013; 8(1): e54897. PMid:23349987 PMCid:PMC3551773. http://dx.doi.org/10.1371/journal. pone.0054897

Anderson BC. Warning about potential for congenital neural larva migrans. J Am Vet Med Assoc 1996; 208(2):185. PMid:8567368.

Avila LFC, Fonseca JSV, Furtado RD, Aguiar PS, Dutra GF, Telmo $\mathrm{PL}$, et al. Registro da transmissão vertical em camundongos BALB/c com toxocarose crônica. Vittalle 2009; 21(1): 9-14.

Beaver PC. The nature of visceral larva migrans. J Parasitol 1969; 55(1):3-12. PMid:5812639. http://dx.doi.org/10.2307/3277335

Bowman DD, Mika-Grieve M, Grieve RB. Circulating excretorysecretory antigen levels and specific antibody responses in mice infected with Toxocara canis. Am J Trop Med Hyg 1987; 36(1):75-82. PMid:3812886.

Burke TM, Roberson EL. Prenatal and lactational transmission of Toxocara canis and Ancylostoma caninum: experimental infection of the bitch before pregnancy. Int J Parasitol 1985; 15(1): 71-75. http://dx.doi. org/10.1016/0020-7519(85)90104-3

Camparoto ML, Fulan B, Colli CM, Paludo ML, Falavigna-Guilherme AL, Fernandez MA. Initial stage of development and migratory behavior of Toxocara canis larvae in BALB/c mouse experimental model. Genet Mol Res 2008; 7(2): 444-450. PMid:18551411. http://dx.doi.org/10.4238/ vol7-2gmr443 
Chieffi PP, Santos SV, Queiroz ML, Lescano SA. Human toxocariasis: contribution by Brazilian researchers. Rev Inst Med Trop Sao Paulo 2009; 51(6): 301-308. PMid:20209265.

Colli CM, Rubinsky-Elefant G, Paludo ML, Paludo ML, Falavigna DL, Guilherme EV, et al. Serological, clinical and epidemiological evaluation of toxocariasis in urban areas of south Brazil. Rev Inst Med Trop Sao Paulo 2010; 52(2): 69-74. PMid:20464126.

De Savigny DH. In vitro maintenance of Toxocara canis larvae and a simple method for the production of Toxocara ES antigen for use in serodiagnostic tests for visceral larva migrans. J Parasitol 1975; 61(4): 781782. http://dx.doi.org/10.2307/3279492

Dunsmore JD, Thompson RC, Bates IA. The accumulation of Toxocara canis larvae in the brains of mice. Int J Parasitol 1983; 13(5): 517-521. http://dx.doi.org/10.1016/S0020-7519(83)80017-4

Dutra GF, Pinto NSF, Avila LFC, Telmo PL, Da Hora VP, Martins LHR, et al. Evaluation of the initial and chronic phases of toxocariasis after consumption of liver treated by freezing or cooling. Parasitol Res 2013; 112(6): 2171-2175. PMid:23494157. http://dx.doi. org/10.1007/s00436-013-3376-5

Fan CK, Lin YH, Du WY, Su KE. Infectivity and pathogenicity of 14-month-cultured embryonated eggs of Toxocara canis in mice. Vet Parasitol 2003; 113(2):145-155. http://dx.doi.org/10.1016/S03044017(03)00046-3

Gallina T, Silva MA, Castro LL, Wendt EW, Villela MM, Berne ME. Presence of eggs of Toxocara spp. and hookworms in a student environment in Rio Grande do Sul, Brazil. Rev Bras Parasitol Vet 2011; 20(2): 176-177. PMid:21722496. http://dx.doi.org/10.1590/ S1984-29612011000200016

Glickman LT, Schantz PM, Cypess RH. Canine and human toxocariasis: review of transmission, pathogenesis, and clinical disease. J Am Vet Med Assoc 1979; 175 (12):1265-1269. PMid:528300.

Hoffmeister B, Glaeser S, Flick H, Pornschlegel S, Suttorp N, Bergmann F. Cerebral toxocariasis after consumption of raw duck liver. Am J Trop Med Hyg 2007; 76(3):600-602. PMid:17360892.

Holland CV, Cox DM. Toxocara in the mouse: a model for parasite-altered host behaviour? J Helminthol 2001; 75(2): 125-135. PMid:11520435.
Jin Z, Akao N, Ohta N. Prolactin evokes lactational transmission of larvae in mice infected with Toxocara canis. Parasitol Int 2008; 57(4): 495-498. PMid:18664391. http://dx.doi.org/10.1016/j.parint.2008.06.006

Kayes SG, Oaks JA. Effect of inoculum size and length of infection on the distribution of Toxocara canis larvae in the mouse. Am J Trop Med Hyg 1976; 25(4): 573-580. PMid:961975.

Lee KT, Min HK, Soh CT. Transplacental migration of Toxocara canis larvae in experimentally infected mice. J Parasitol 1976; 62(3): 460-465. PMid:932920. http://dx.doi.org/10.2307/3279158

Maffrand R, Avila-Vazquez M, Princich D, Alasia P. Congenital ocular toxocariasis in a premature neonate. Ann Pediat 2006; 64(6): 595-604

Oliveira-Sequeira TC, Amarante AF, Ferrari TB, Nunes LC. Prevalence of intestinal parasites in dogs from Sao Paulo State, Brazil. Vet Parasitol 2002; 103(1-2): 19-27. http://dx.doi.org/10.1016/S03044017(01)00575-1

Pawlowski Z. Toxocariasis in humans: clinical expression and treatment dilemma. J Helminthol 2001; 75(4): 299-305. PMid:11818044. http:// dx.doi.org/10.1017/S0022149X01000464

Reiterová K, Tomasovicová O, Dubinský P. Influence of maternal infection on offspring immune response in murine larval toxocariasis. Parasit Immunol 2003; 25(7): 361-368. http://dx.doi.org/10.1046/ j.1365-3024.2003.00642.x

Sariego I, Kanobana K, Junco R, Vereecken K, Núñez FA, Polman $\mathrm{K}$, et al. Frequency of antibodies to Toxocara in Cuban schoolchildren. Trop Med Int Health 2012; 17(6): 711-714. PMid:22943301. http:// dx.doi.org/10.1111/j.1365-3156.2012.02996.x

Villela MM, Pepe MS, Ferraz ML, Morais NCM, Araujo EB, Ruas JL, et al. Contaminação ambiental da orla da Laguna dos Patos (Pelotas, RS, Brasil), por parasitos com potencial zoonótico. Vitalle 2009; 21(2): 69-74.

Yamashita T, Freigang S, Eberle C, Pattison J, Gupta S, Napoli C, et al. Maternal Immunization Programs Postnatal Immune Responses and Reduces Atherosclerosis in Offspring. Circ Res 2006; 99(7): E51-64. PMid:16946133. http://dx.doi.org/10.1161/01. RES.0000244003.08127.cc 